Anuario Latinoamericano Ciencias Políticas

y Relaciones Internacionales vol. 11, 2021

pp. 83-98

\section{Indicators of Authoritarian Behavior of Political Leaders. The Bolsonaro Case (2019-2020)}

\section{Indicadores de comportamiento autoritario de líderes políticos: el caso Bolsonaro (2019-2020)}

\author{
Adriano de Oliveira Othon ${ }^{\star}$ \\ INSTITUTE OF SOCIAL AND POLITICAL SCIENCES \\ UNIVERSITY OF LISBON \\ LISBON, PORTUGAL \\ $\triangle$ adriano_othon@hotmail.com \\ https://orcid.org/0000-0003-3834-7002
}

DOI:10.17951/al.2021.11.83-98

\begin{abstract}
Based on indicators of the authoritarian behavior of political leaders developed by Levitsky and Ziblatt (2018), this paper examines the political discourse, stances, and attitudes of Jair Bolsonaro, president of Brazil, during his first two years in office. The research uses a qualitative case study approach centered on literature review, with emphasis on chapters of books and journal articles, as well as news reports for an empirical observation of the behavior of the president of Brazil concerning rules and institutions of democracy. The essentially authoritarian behavior of Bolsonaro signals a trend toward democratic regression in Brazil; however, it is not technically correct to affirm that Brazil is already being governed through an authoritarian regime.
\end{abstract}

KEYWORDS: democracy, authoritarianism, Brazil, Bolsonaro.

\section{RESUMEN}

Basándose en los indicadores del comportamiento autoritario de líderes políticos desarrollados por Levitsky y Ziblatt (2018), el autor del artículo examina el discurso político, la postura y las actitudes del presidente de Brasil, Jair Bolsonaro, en los dos primeros años de ejercicio de su mandato. La investigación utiliza un estudio de caso con un enfoque cualitativo basado en la revisión bibliográfica, con un énfasis en los capítulos de libros y artículos científicos, así como los materiales periodísticos, para

* Master's student in Political Science at the Institute of Social and Political Sciences, University of Lisbon (ISCSP-ULisboa). Bachelor's Degree in Law from the Federal University of Rio Grande do Norte (Natal, Rio Grande do Norte, Brazil). 
Dossier América Latina: Brasil permitir una observación empírica de la conducta del presidente brasileño frente a las instituciones y las normas democráticas. Se observa que Bolsonaro en realidad tiene un comportamiento autoritario, que señala una tendencia de regresión democrática en Brasil, aunque técnicamente no es correcto afirmar que el país ya esté bajo un régimen autoritario.

PALABRAS CLAVE: democracia, autoritarismo, Brasil, Bolsonaro.

\section{Introduction}

Based on a set of key indicators of authoritarian behavior of political leaders, as developed by Levitsky and Ziblatt (2018), this article examines the political discourse, stances, and attitudes of the president of Brazil, Jair Bolsonaro, during his first two years in office, which began in January 2019. This time frame does not include the period of more than two decades that Bolsonaro spent as a congressman, nor his campaign-based declarations. Instead, it focuses on his performance as president to verify whether he can be classified as authoritarian under the adopted model.

This research takes part in the debate about the onset of a new global wave of authoritarianism, either in countries with an already consolidated tradition of democracy, or where the democratic process is still gathering momentum. Brazil, whose re-democratization process took place in the 1980s, after two decades of military dictatorship, is currently in the second category. Contrary to what has traditionally taken place in the $20^{\text {th }}$ century in Latin America, when authoritarian systems generally came to power through violence and State-based military coups, many contemporary societies have witnessed the rise of leaders with authoritarian behavior legitimized through popular vote. Once elected and able to exercise their power, they start to systematically violate the rules of democracy.

This article focuses on the following research question: Is it possible to formally categorize the president of Brazil, Jair Bolsonaro, as a political leader with authoritarian behavior? In this respect and based on the test for authoritarianism proposed by the aforementioned authors, the general objective of this article is to critically analyze the period of two years that Jair Bolsonaro served so far as the president of Brazil. Note that due to the limitations of this research, it is not possible to proceed to a profound analysis on the entire range of political phenomena usually associated with authoritarianism, such as populism or democratic regression; however, these topics may still be briefly addressed throughout this text.

In terms of relevance, this article aims to contribute to the set of observations concerning the current situation and the paths of democracy in Brazil, which - due to its geographic dimensions and regional economic weight levies an additional impact on its Latin American neighbors. This research is 
further justified by the currency of the core material, enabling an empirical observation of the behavior of the president of Brazil concerning rules and institutions of democracy during his first two years in office.

Even though there is academic research in political science that examines the start of the Bolsonaro mandate, the literature review has not found any previous study using the theoretical framework proposed here. Neto and Pimenta (2020) analyze the first year of Jair Bolsonaro's role as president, but through a comparative approach to two other presidential periods: Jânio Quadros (from January to August 1961) and Fernando Collor (from March 1990 to December 1992). As a result, the authors declare that despite Bolsonaro having experienced what appears to be a level of conflict similar to that of the presidents mentioned above during his first year in office, the distinctive characteristics of Bolsonaro's mandate center on his intimate relationship with the leaders of the Armed Forces and the solid support of the conservative evangelical electorate.

Methodologically, this research was carried out employing a case study delimited on a geographical and chronological basis but focused on understanding a more complex and comprehensive phenomenon: the growth of institutional authoritarian manifestations in democratic systems. A qualitative approach was adopted based on bibliographical research and through a specific emphasis on the work of Levitsky and Ziblatt (2018) but also supported by chapters from other books and journal articles, in addition to using news reports available on the internet to verify the practical validity of each of the indicators of authoritarian behavior. This case study has predominantly empirical-descriptive characteristics, focused on assessing the elected case within its actual context: the first two years of Jair Bolsonaro's mandate as the president of Brazil.

\section{Democracy and authoritarianism}

At a factual level, the analysis undertaken in this research looks at the behavior of a specific political leader, elected according to the rules of a democratic system but with overtones of supposedly authoritarian conduct. In this scenario, understanding the concepts of democracy and authoritarianism (in addition to the hybrid competitive authoritarianism regime) is fundamental for the objectives of this article.

In general terms, this article adopts the concept of representative democracy advocated by the pluralist theoretical model currently prevalent in contemporary political science, which among its principal exponents includes Robert Dahl, Arthur Bentley, David Truman, and Charles Lindblom (Smith, 1997). This theoretical approach is founded on the basis of society with multiple centers of power - not just the exclusive exercising of power by a specific class or group - in addition to the instruments that ensure the freedom of
Indicators of Authoritarian Behavior of Political Leaders. The Bolsonaro Case (2019-2020)

Adriano de Oliveira Othon 
Dossier América Latina: Brasil political participation by its citizens in electing their chosen representatives (Costa, 2007).

Democracy, according to Dahl (1989), is a governing system that meets the following seven primordial conditions: i) "elected officials"; ii) "free and fair elections"; iii) "inclusive suffrage"; iv) "right to run for office"; v) "freedom of expression"; vi) "alternative information"; and vii) "associational autonomy" (p. 221). More recently, Levitsky and Way (2010) added another attribute: "the existence of a reasonably level playing field between incumbents and opposition” (p. 5).

According to Linz (1964), authoritarianism is a political system

with limited, not responsible, political pluralism; without elaborate and guiding ideology (but with distinctive mentalities); without intensive nor extensive political mobilization (except some points in their development); and in which a leader (or occasionally a small group) exercises power within formally ill-defined limits but actually quite predictable ones. (p. 297)

Somewhere between these two concepts, there is a kind of hybrid authoritarianism that is discussed in the works of Levitsky and Way (2010), which presents characteristics of democracy and authoritarianism described as competitive authoritarianism. In this system, there are legal and relatively effective channels allowing opposition parties to compete for power, with elections being held regularly in which opposition parties are not legally prevented from competing. However, one of the distinctive characteristics of this system, even though democratic institutions are respected enough to enable real competition, is that they can be violated in such a manner that competition is often unfair, with opposition parties being impaired from seriously challenging those in power. The authors' examples concerning the absence of material equality for competition-based conditions are disparities in financial resources and insufficient access to the media.

Note that the aforementioned concepts do not necessarily signify a claim to a hermetic and inflexible definition of democracy and authoritarianism, but instead a perception of its principal characteristic elements. Due to their complex socio-political phenomena, these elements must always be interpreted by those who take part, their individual circumstances, and the periods over which they occur.

Through this conceptual framework, it is possible to classify the Brazilian government system as democratic, even though it is not necessarily a fully consolidated democracy. According to The Economist Intelligence Unit (2021), Brazil is classified as a "flawed democracy," which is currently positioned in its annual ranking system in $49^{\text {th }}$ place out of a total of 167 countries ${ }^{1}$.

\footnotetext{
1 According to the democracy index of The Economist Intelligence Unit (2021), there are four democratic quality classifications, listed in descending order: full democracies, flawed democracies, hybrid regimes, and authoritarian regimes.
} 
In turn, the most recent report from the V-Dem Institute (2021) classifies the Brazilian system as an "electoral democracy" nings about Brazil being on a democratic decline. According to this document (p. 19), among the ten countries that have "autocratized" the most over the last decade, there are once-stable democracies such as Poland $\left(1^{\text {st }}\right)$, Hungary $\left(2^{\text {nd }}\right)$, Turkey $\left(3^{\text {rd }}\right)$, Brazil $\left(4^{\text {th }}\right)$, Serbia $\left(5^{\text {th }}\right)$ and India $\left(7^{\text {th }}\right)$.

Democracy in Brazil - or any other part of the world - cannot be classified as an absolutely assured achievement free from setbacks or downturns and, as such, immune to an authoritarian jolt. The fact that Brazil has not achieved full democratic consolidation further emphasizes this risk.

The process of slowly and gradually losing democratic quality - especially about "competitive electoral procedures, civil and political liberties, and accountability" - is characteristic of democratic backsliding (Lust \& Waldner, 2015, p. 2). This phenomenon has been the subject of studies by multiple authors in recent years, with subtle terminological distinctions such as democratic recession or democratic regression (Diamond, 2015, 2021), democratic decline (Plattner, 2015), democratic decay (Daly, 2019), and de-democratization (Enyedi, 2016). This particular case study is based on this precept, supported by the recent work of Levitsky and Ziblatt (2018).

\section{Test for authoritarianism - indicators of authoritarian behavior applied to the case of President Bolsonaro}

Inspired by the studies of Linz (1978), Levitsky and Ziblatt (2018) developed the following set of four key indicators of authoritarian behavior by political leaders that potentially put democracy at risk: "1) rejects, in words or action, the democratic rules of the game, 2) denies the legitimacy of opponents, 3) tolerates or encourages violence, or 4) indicates a willingness to curtail the civil liberties of opponents, including the media" (p. 18). Table 1 contains a number of questions to be considered as a test for authoritarianism.

\section{Rejection of (or weak commitment to) democratic rules of the game}

Application of this test for authoritarianism in relation to President Bolsonaro begins with an affirmative response to question 1.a (Do they reject the Constitution or express a willingness to violate it?).

The Brazilian president has already expressed a willingness to violate the Brazilian Constitution by endorsing the Armed Forces' potential inter-

\footnotetext{
2 According to the V-Dem Institute (2021), there are four classifications of democratic quality: liberal democracies, electoral democracies, electoral autocracies, and closed autocracies.
}

Indicators of Authoritarian Behavior of Political Leaders. The Bolsonaro Case (2019-2020)

Adriano de Oliveira Othon 
América Latina: Brasil

Table 1.

Four key indicators of authoritarian behavior
1. Rejection of (or weak commitment to) democratic rules of the game

\section{Denial of the legitimacy of political opponents}

\section{Toleration or encouragement of violence}
4. Readiness to curtail civil liberties of opponents, including media

a) Do they reject the Constitution or express a willingness to violate it?

b) Do they suggest a need for antidemocratic measures, such as canceling elections, violating or suspending the Constitution, banning certain organizations, or restricting basic civil or political rights?

c) Do they seek to use (or endorse the use of) extraconstitutional means to change the government, such as military coups, violent insurrections, or mass protests aimed at forcing a change in the government?

d) Do they attempt to undermine the legitimacy of elections, for example, by refusing to accept credible electoral results?

a) Do they describe their rivals as subversive, or opposed to the existing constitutional order?

b) Do they claim that their rivals constitute an existential threat, either to national security or to the prevailing way of life?

c) Do they baselessly describe their partisan rivals as criminals, whose supposed violation of the law (or potential to do so) disqualifies them from full participation in the political arena?

d) Do they baselessly suggest that their rivals are foreign agents, in that they are secretly working in alliance with (or the employ of) a foreign government- usually an enemy one?

a) Do they have any ties to armed gangs, paramilitary forces, militias, guerrillas, or other organizations that engage in illicit violence?

b) Have they or their partisan allies sponsored or encouraged mob attacks on opponents?

c) Have they tacitly endorsed violence by their supporters by refusing to unambiguously condemn it and punish it?

d) Have they praised (or refused to condemn) other significant acts of political violence, either in the past or elsewhere in the world?

a) Have they supported laws or policies that restrict civil liberties, such as expanded libel or defamation laws or laws restricting protest, criticism of the government, or certain civic or political organizations?

b) Have they threatened to take legal or other punitive action against critics in rival parties, civil society, or the media?

c) Have they praised repressive measures taken by other governments, either in the past or elsewhere in the world?

Source: adapted from Levitsky and Ziblatt (2018, pp. 18-19). 
vention in the event of a political dispute between the branches of power, known among his supporters as "military intervention." In a ministerial meeting recorded on video, which subsequently went public, Bolsonaro, who had been in conflict with the Federal Supreme Court (STF) due to authorized criminal investigations into his sons, stated that he could trigger Article 142 of the Brazilian Constitution ${ }^{3}$, including the possibility that the Armed Forces could reestablish order. This is a distorted and unsustainable interpretation of the constitutional provision, which started with blog posts on the internet and was subsequently rejected by Brazil's principal jurists as equivalent to predicting the own constitutional order's breakdown $(\mathrm{G} 1,2020$, June 2$)$. In reality, the article deals with the organization and duties of the Armed Forces and not the relationship or the separation of the government powers.

In terms of question 1.b (Do they suggest a need for antidemocratic measures, such as canceling elections, violating or suspending the Constitution, banning certain organizations, or restricting basic civil or political rights?), the response is equally affirmative, specifically concerning the mitigation of the fundamental rights of expression of thought and the ability to meet in locations open to the general public, as enshrined in the Brazilian Constitution ${ }^{4}$.

In recent popular pro-democracy and anti-government demonstrations, Bolsonaro called such demonstrators "addicts," "thugs" and "terrorists" (Público, 2020, June 5), in addition to threatening to use the National Public Security Force - consisting of police officers subordinate to the Ministry of Justice - against activities that could be identified as anti-fascist (Deutsche Welle, 2020, June 5).

Item 1.c (Do they seek to use [or endorse the use of] extra-constitutional means to change the government, such as military coups, violent insurrections or mass protests aimed at forcing a change in the government?), which also has an affirmative response, illustrates Bolsonaro's endorsement and admiration to the Brazilian military dictatorship (1964-1985), something recurring throughout his parliamentary career.

3 Constitution of the Federative Republic of Brazil (CFRB), Article 142, caput: "The Armed Forces, comprised of the Navy, the Army and the Air Force, are permanent and regular national institutions, organized on the basis of hierarchy and discipline, under the supreme authority of the President of the Republic, and are intended for the defense of the Country, for the guarantee of the constitutional powers, and, on the initiative of any of these, of law and order" (Senado Federal, 2013, p. 85).

4 CFRB, Article 5: "All persons are equal before the law, without any distinction whatsoever, Brazilians and foreigners residing in the country being ensured of inviolability of the right to life, to liberty, to equality, to security and to property, on the following terms: (...) IV - the expression of thought is free, and anonymity is forbidden; (...) XVI - all persons may hold peaceful meetings, without weapons, in places open to the public, regardless of authorization provided that they do not frustrate another meeting previously called for the same place, subject only to prior notice to the competent authority; (...)" (Senado Federal, 2013, p. 13).
Indicators of Authoritarian Behavior of Political Leaders. The Bolsonaro Case (2019-2020)

Adriano de Oliveira Othon 
Dossier América Latina: Brasil

In a symptomatic manner, amid popular protests in his support, banners and posters have been raised exalting Institutional Act No. 5 (AI-5), a decree from 1968 that inaugurated the darkest and most violent decade of the dictatorship, which repealed mandates served by members of the opposition, suspended constitutional guarantees, and led to the institutionalized torture of opponents to the system, plus having other harmful consequences. Such protests and demonstrations stemmed from tensions between Bolsonaro and the then President of the House of Representatives, Rodrigo Maia, with the most prominent of these taking place in front of the Army Headquarters in Brasilia, with Bolsonaro being present himself in an address to demonstrators (Exame, 2020, April 19). At no moment in time did he rebuke the praise of AI-5.

Ultimately, the response to question 1.d (Do they attempt to undermine the legitimacy of elections, for example, by refusing to accept credible electoral results?) is also affirmative. The Brazilian electoral system, although it could still be improved, is internationally recognized for its efficiency, safety, and transparency in the way that it promotes elections and discloses its results. There are no records of any fraud linked to the use of electronic ballot boxes, implemented more than two decades ago and having been used on an interrupted basis since then. This was pointed out, for example, by the Electoral Observation Mission of the Organization of American States (EOM/OAS) during the 2018 presidential elections (OAS, 2018).

Bolsonaro, however, fielded the theory - which was vastly disseminated across the Brazilian extreme right - that the electronic voting system used throughout Brazil is not reliable or trustworthy. On that occasion, in a speech to Brazilian supporters in Miami (USA), he stated that he had proof that electronic ballot boxes were frauded during the 2018 presidential election and that he apparently would have received enough votes to be elected during the first round of voting (the election was effectively decided after the second round of voting) (BBC, 2020, March 10). Despite this serious and hard-hitting declaration, he never presented any form of proof.

It is indeed symptomatic that Bolsonaro remained faithful to the false allegations of fraud made by Donald Trump during the presidential elections of the United States, having been the last president of the countries that comprise G20 - the forum that brings together the world's most important economies - to congratulate Joe Biden on his election victory. He only did so a day after the Electoral College endorsed the election result (El País, 2020, December 15).

Such examples satisfactorily demonstrate Bolsonaro's lack of compromise to the rules of democracy. This type of public stance has occurred when being pressured by public opinion or other political actors, which is natural in democratic systems but has resulted in clashes and even institutional crises, making the Brazilian president's authoritarian penchants even more evident. 


\section{Denial of the legitimacy of political opponents}

At this point, although less frequently, Bolsonaro's behavioral patterns are consistent with indicators of authoritarianism.

The affirmative response to item 2.a (Do they describe their rivals as subversive or opposed to the existing constitutional order?) reemphasizes the manner in which the president of Brazil treats his political rivals, such as the governor of the State of Maranhão, Flávio Dino, a member the Brazilian Communist Party (PCdoB). During a recent inauguration of federal government infrastructure works in this state, Bolsonaro, in addition to not inviting the state governor himself - contrary to institutional practice - affirmed during the event that communism would soon be eradicated from Brazil. That very same week, he had stated to supporters in Brasilia: "We have to remove the PCdoB from there, man, for God's sake. It's only here in Brazil that communists declare that they are democrats" (Congresso em Foco, 2020, October 29). This last statement, incidentally, reveals the strategy of leveling an accusation of being undemocratic on political opponents, a tactic that he started to use as an attempt to distance himself from the same image.

In terms of question 2.b (Do they claim that their rivals constitute an existential threat, either to national security or to the prevailing way of life?), the authoritarian behavior of Bolsonaro is emphasized through the use of the National Security Law (Planalto, 1983) in relation to critical speeches directed at the government. This type of law dates back to the military dictatorship but remains in force, either because no other law has expressly revoked it or because the STF has never judged its compliance with the new constitutional order initiated in 1988. Making the most of the legal nature of this fact, Bolsonaro used this law to threaten exPresident Lula (Deutsche Welle, 2019, November 21), as well as ministers of his government have been using it as the legal basis to legally sue journalists and even one of the STF Ministers, Gilmar Mendes (Carta Capital, 2020, July 24).

\section{Toleration or encouragement of violence}

Here, as in the previous subsections, the behavior of the Brazilian president once again fits into the indicators proposed by Levitsky and Ziblatt (2018).

In terms of item 3.a (Do they have any ties to armed gangs, paramilitary forces, militias, guerrillas or other organizations that engage in illicit violence?), Bolsonaro and his sons (one of these being a Federal Senator who is under criminal investigation for such a crime), in addition to having intimate connections with members of armed militias (El País, 2020, June 20), adopts a form of discourse that actually supports the actions of these criminals ${ }^{5}$.

5 In terms of the current situation in Brazil, militias are criminal organizations that mostly consist of members or ex-members of security forces (police, firefighters, and members of the Armed Forces) that dominate territories in poor communities and also commit assassinations,
Indicators of Authoritarian Behavior of Political Leaders. The Bolsonaro Case (2019-2020)

Adriano de Oliveira Othon 
Dossier América Latina: Brasil

The political scientist Bruno Paes Manso - a scholar on the subject - reveals glimpses of this ideological connection to Bolsonaro's rhetoric, which embodies "the concept of breakdown imposed by force, of reinventing politics by means of an authority that will impose itself and restore traditional values through violence, even if the law is disregarded during the process" (Deutsche Welle, 2020, October 7).

In relation to question 1.b (Have they or their partisan allies sponsored or encouraged mob attacks on opponents?), Bolsonaro, from a context of rhetorical clashes with state governors over the accuracy of the statistics on the sick and dead caused by COVID-19, encouraged his supporters to enter public hospitals to physically check the usage of beds (IstoÉ, 2020, June 12). As a result, there were incidences of invasion and depredation of hospitals that very same day, even in wards restricted to doctors and patients (Exame, 2020, June 12).

The analysis of the item 1.d (Have they praised [or refused to condemn] other significant acts of political violence, either in the past or elsewhere in the world?) once again emphasizes Bolsonaro's predilection for dictatorial systems and their methods. In response to criticism from the United Nations High Commissioner for Human Rights, Michelle Bachelet, whose father was imprisoned, tortured, and killed at the beginning of the Chilean dictatorship of Augusto Pinochet (1973 to 1990), the Brazilian president made a post on the internet declaring that Chile "failed to turn into another Cuba thanks to those who had the courage to put a stop to the left in 1973, with her father, a brigadier at the time, being one of these communists" (Veja, 2019, September 4).

A month beforehand, Bolsonaro had extolled the deceased colonel Brilhante Ustra, ex-leader of the Detachment of Information Operations - Center for Internal Defense Operations (DOI-CODI), a political repression organization of the Brazilian military dictatorship, as a "national hero." According to the National Truth Commission (2011-2014), Ustra was directly or indirectly responsible for the torture and murder of dozens of political prisoners when he was in charge of this organization from 1970 to 1974 (G1, 2019, August 8).

\section{Readiness to curtail civil liberties of opponents, including media}

Additionally, mitigation of civil liberties was highly evident during the first two years of Bolsonaro's rule, thus responding in the affirmative to the three questions set out in this subsection.

In line with the rhetoric of the president of Brazil against protests in the street, there has been a significant increase in bills made by the National Con-

extortions and carry out other illicit activities under the pretense of helping to combat drug trafficking or other types of offenses, with concentrated activity in the Brazilian state of Rio de Janeiro (Congresso em Foco, 2019, December 23). 
gress aimed at restricting fundamental constitutional rights of expression of thought and the ability to meet in places open to the public. This fact brings about question 4.a (Have they supported laws or policies that restrict civil liberties, such as expanded libel or defamation laws or laws restricting protest, criticism of the government, or certain civic or political organizations?).

One of these legislative proposals, initiated by the Bolsonaro government, amplifies cases of exclusion of illegality for the potential coming into force of a decree for the Guarantee of Law and Order (GLO), i.e., assignments of the Armed Forces over a limited period, exclusively determined by express order of the Presidency of the Republic, in cases where traditional public security forces are insufficient. Under the pretext of curbing violent popular demonstrations, this bill increases the likelihood that security services (police, firefighters, or military personnel in the Armed Forces) could be exempt from criminal punishment if their conduct is considered to be in self-defense (Agência Brasil, 2019, November 25).

Among the other proposals aimed at mitigating popular demonstrations (it is estimated that of the 70 passed so far through the National Congress, 21 were presented in 2019 alone), the most prominent are as follows: criminalizing the use of masks and the blocking of streets; increasing penalties for crimes of being in contempt of the police; permission by the police - with no judicial authorization - to monitor people through genetic mapping and private messages on social networks, in addition to infiltrating agents and intercepting telephone calls; and, classifying acts of violence based on political and ideological motivation as crimes of terrorism (Folha de S. Paulo, 2020, January 10).

Relative to point 4.b (Have they threatened to take legal or other punitive action against critics in rival parties, civil society, or the media?), Bolsonaro has directed numerous threats at the press, with which he has regular skirmishes.

On more than one occasion, the Brazilian president declared that television broadcasters who convey the news to supposedly destabilize him would have difficulties when it comes to the renewal process of respective public concessions for broadcasting services for sound and images. One of his preferred targets is Rede Globo (Globo Network), the leading private television broadcaster in Brazil, to whom Bolsonaro has referred to as the "gutter press, garbage," and whose concession is required to be renewed in 2022, the final year of his presidential mandate. Non-renewal of the Globo Network concession is a banner frequently seen at demonstrations held by the president's supporters (Congresso em Foco, 2020, April 30; IstoÉ, 2019, October 29).

Ultimately, in the same way as the two previous passages in this subsection, the response to item 4.c (Have they praised repressive measures taken by other governments, either in the past or elsewhere in the world?) is also affirmative. To provide yet another example of Bolsonaro's devotion to the Brazilian dictatorship, in his first year in office, the anniversary of the 1964 military coup
Indicators of Authoritarian Behavior of Political Leaders. The Bolsonaro Case (2019-2020)

Adriano de Oliveira Othon 
Dossier América Latina: Brasil was "commemorated" via a bulk message campaign on WhatsApp through an electronic account of the Communication Secretariat of the Presidency, consisting of a two-minute-long video in which the presenter recounted his own version of Brazilian history, where the military saved Brazil from a supposedly communist dominion. The account from which this information was disseminated is intended to be used for federal government public utility, news, and service-based messages (UOL, 2019, March 31).

\section{A young democracy facing the authoritarian threat}

After the result of the 2018 presidential elections in Brazil, there was hope among politicians and opposition voters alike that Bolsonaro's aggressive and undemocratic attitude would not be put into practice after taking office. As such, the required liturgy of the role would naturally moderate the future president's potential authoritarian outbursts. It can be affirmed that any such expectation did not come to fruition.

Relying on popular approval that - minus a few exceptions - had oscillated between 30 and 40 percent (CNI-IBOPE, 2020; Datafolha, 2021), involving the backing of relevant private initiative sectors (e.g., the financial market), a strong link with personnel from the Armed Forces, the solid support of conservative evangelicals and a divided and weakened opposition, instead of slackening his authoritarian behavior, Bolsonaro went on to exacerbate it.

Levitsky and Ziblatt (2018) emphasize in their body of work that a powerful politician's fulfillment of even one of the indicators discussed above would be enough to inspire concern over the integrity of democracy. Thus, we can determine that Bolsonaro's attitudes are affirmative to nearly all of the tested items, emphasizing the danger faced by Brazilian democracy under his rule. In addition to the obvious risks of democratic backsliding through his direct activities, there is also the collateral effect on other spheres of power, including an increase in politicians with similar or even greater authoritarian tendencies.

Based on the aforementioned indicators and in response to the original question of whether the president of Brazil, Jair Bolsonaro, can be formally classified as a political leader with authoritarian behavior, the answer is certainly affirmative. The qualitative approach used in this article makes it difficult to provide a precise estimate of the degree of regression experienced by Brazilian democracy since the election of Bolsonaro, but it does confirm that there has been a move in this direction. However, according to the concepts described in the second section of this article, it cannot be upheld that Brazil is effectively under an authoritarian regime.

In spite of imperfections, Brazilian democracy retains certain attributes that underline its resilience. Important sectors of civil society remain organized, the Judiciary branch of power is independent, there is a robust institutional apparatus for the protection of rights - with emphasis on the Public 
Ministry - and the press retains a good measure of freedom (Daly, 2019). Resilient democratic institutions are pointed out as one of the major defenses of Western societies against the recently emerging authoritarian forces and the democratic backsliding (Norris, 2017). The capacity of these multiple elements to successfully operate is decisive for the vitality of the Brazilian democracy in the future.

\section{Conclusions}

This article constitutes an effort to understand the concepts of democracy and authoritarianism on the basis of the framework of authoritarian behavioral indicators of political leaders, as established by Levitsky and Ziblatt (2018), having been applied in a clear and systematic manner for the case in question: the first two years of the rule of Jair Bolsonaro, president of Brazil.

Taking the core question into account, it has been empirically verified that the Brazilian president adopts political discourse, stances, and attitudes of an authoritarian nature, emphasizing a tendency for democratic regression in Brazil, but it is still not technically accurate to affirm that the situation has degenerated into an authoritarian regime.

Through a qualitative analysis of the democratic regression observed in Brazil or through the impacts of the revisionist and obscurantist stance of the president of Brazil during the COVID-19 pandemic, there is definitely more room for further in-depth investigations into the central topic of this article, plus further analysis of the subject matter that surrounds it.

\section{Bibliographic references}

Agência Brasil. (2019, November 25). Bolsonaro defende excludente de ilicitude contra protestos violentos. Retrieved February 17, 2021, from https://agenciabrasil.ebc.com.br/politica/ noticia/2019-11/bolsonaro-defende-excludente-de-ilicitude-contra-protestos-violentos

BBC. (2020, March 10). Questionado sobre provas, Bolsonaro diz que brasileiros não confiam no sistema eleitoral. Retrieved February 5, 2021, from https://www.bbc.com/portuguese/ brasil-51822918

Carta Capital. (2020, July 24). Revivida por Bolsonaro, Lei de Segurança Nacional entra na mira. Retrieved February 12, 2021, from https://www.cartacapital.com.br/politica/ revivida-por-bolsonaro-lei-de-seguranca-nacional-entra-na-mira/

CNI-IBOPE. (2020). Pesquisa CNI-IBOPE: Avaliação do Governo. Retrieved March 4, 2021, from https://www.portaldaindustria.com.br/estatisticas/pesquisa-cni-ibope-avaliacao-dogoverno/

Congresso em Foco. (2020, April 30). Bolsonaro ameaça não renovar concessão da Globo em 2022. Retrieved February 17, 2021, from https://congressoemfoco.uol.com.br/midia/ bolsonaro-ameaca-nao-renovar-concessao-da-globo-em-2022/
Indicators of Authoritarian Behavior of Political Leaders. The Bolsonaro Case (2019-2020)

Adriano de Oliveira Othon 
Dossier América Latina: Brasil
Congresso em Foco. (2019, December 23). Dez fatos que ligam a família Bolsonaro a milicianos. Retrieved February 16, 2021, from https://congressoemfoco.uol.com.br/ congresso-em-foco/dez-fatos-que-ligam-a-familia-bolsonaro-a-milicianos/

Congresso em Foco. (2020, October 29). Sob gritos de "Fora, Flávio Dino", Bolsonaro fala em erradicar o comunismo. Retrieved February 8, 2021, from https://congressoemfoco.uol.com. br/governo/sob-gritos-de-fora-flavio-dino-bolsonaro-fala-em-erradicar-o-comunismo/

Costa, H. O. (2007). Democracia e participação na teoria pluralista. Cronos, no. 8(1), pp. 215-228. Retrieved January 22, 2021, from https://periodicos.ufrn.br/cronos/article/ view/3175/2565

Dahl, R. A. (1989). Democracy and Its Critics. New Haven, CT: Yale University Press.

Daly, T. G. (2019, March). Populism, public law, and democratic decay in Brazil: Understanding the rise of Jair Bolsonaro. Paper presented at the $14^{\text {th }}$ International Human Rights Researchers' Workshop "Democratic Backsliding and Human Rights", Ramat Gan, Israel. https://doi.org/10.2139/ssrn.3350098

Datafolha. (2021). Opinião Pública " Avaliação de Governo " Presidente " Jair Bolsonaro. Retrieved March 4, 2021, from http://datafolha.folha.uol.com.br/opiniaopublica/ avaliacaodegoverno/presidente/jairbolsonaro/indice-1.shtml

Deutsche Welle. (2020, June 5). Bolsonaro ameaça acionar Força Nacional em atos contra o governo. Retrieved February 3, 2021, from https://p.dw.com/p/3dJmF

Deutsche Welle. (2019, November 21). Lei de Segurança Nacional, um resquício da ditadura. Retrieved February 12, 2021, from https://p.dw.com/p/3TQLw

Deutsche Welle. (2020, October 7). "Ligação de Bolsonaro com milícias é, acima de tudo, ideológica". Retrieved February 16, 2021, from https://p.dw.com/p/3jYpT

Diamond, L. (2015). Facing Up to the Democratic Recession. Journal of Democracy, no. 26(1), pp. 141-155. https://doi.org/10.1353/jod.2015.0009

Diamond, L. (2021). Democratic regression in comparative perspective: Scope, methods, and causes. Democratization, no. 28(1), pp. 22-42. https://doi.org/10.1080/13510347.2020 .1807517

El País. (2020, December 15). Bolsonaro é o último presidente do G20 a parabenizar Biden: "Pronto a trabalhar com o novo governo". Retrieved March 1, 2021, from https://brasil.elpais. com/internacional/2020-12-15/bolsonaro-e-o-ultimo-presidente-do-g20-a-parabenizarbiden-estarei-pronto-a-trabalhar-com-o-novo-governo.html

El País. (2020, June 20). Trama para esconder Queiroz e ajudar Adriano da Nóbrega joga a milícia no coração da família Bolsonaro. Retrieved February 16, 2021, from https:// brasil.elpais.com/brasil/2020-06-20/trama-para-esconder-queiroz-e-ajudar-adriano-danobrega-joga-a-milicia-no-coracao-da-familia-bolsonaro.html

Enyedi, Z. (2016). Populist polarization and party system institutionalization: The role of party politics in de-democratization. Problems of Post-Communism, no. 63(4), pp. 210-220. https://doi.org/10.1080/10758216.2015.1113883

Exame. (2020, April 19). Bolsonaro discursa para manifestação com faixa "Fora Maia" e apoio ao AI-5. Retrieved February 3, 2021, from https://exame.com/brasil/bolsonarodiscursa-para-manifestacao-com-faixa-fora-maia-e-apoio-ao-ai-5/

Exame. (2020, June 12). Grupo invade ala da covid-19 em hospital no RJ e exige "checar leitos". Retrieved February 16, 2021, from https:/exame.com/brasil/grupo-invade-ala-dacovid-19-em-hospital-no-rj-e-exige-checar-leitos/ 
Folha de S. Paulo. (2020, January 10). Explode o número de projetos de lei que restringem o direito aprotesto. Retrieved February 17, 2021, from https://www1.folha.uol.com.br/cotidiano/2020/01/ explode-numero-de-projetos-de-lei-que-restringem-direito-a-protesto.shtml

G1. (2019, August 8). Bolsonaro chama coronel Brilhante Ustra de 'herói nacional'. Retrieved February 16, 2021, from https://g1.globo.com/politica/noticia/2019/08/08/bolsonarochama-coronel-ustra-de-heroi-nacional.ghtml

G1. (2020, June 2). O que é o artigo 142 da Constituição, que Bolsonaro citou ao pedir intervenção das Forças Armadas. Retrieved February 2, 2021, from https://g1.globo.com/ politica/noticia/2020/06/02/o-que-e-o-artigo-142-da-constituicao-que-bolsonaro-citouao-pedir-intervencao-das-forcas-armadas.ghtml

IstoÉ. (2020, June 12). Bolsonaro: Apoiadores devem "arranjar um jeito" de entrar em hospitais para checar ocupação. Retrieved February 16, 2021, from https://istoe.com.br/ bolsonaro-incentiva-invasao-a-hospitais-para-checar-ocupacao/

IstoÉ. (2019, October 29). Bolsonaro ameaça não renovar concessão da Rede Globo: 'Vai ter dificuldade'. Retrieved February 17, 2021, from https://istoe.com.br/bolsonaro-ameacanao-renovar-concessao-da-rede-globo-vai-ter-dificuldade/

Levitsky, S. \& Way, L. A. (2010). Competitive Authoritarianism: Hybrid Regimes after the Cold War. Cambridge, England: Cambridge University Press. https://doi.org/10.1017/ CBO9780511781353

Levitsky, S. \& Ziblatt, D. (2018). How Democracies Die. New York, NY: Crown Publishing.

Linz, J. J. (1964). An Authoritarian Regime: Spain. In E. Allardt \& Y. Littunen (Eds.), Cleavages, Ideologies, and Party Systems: Contributions to Comparative Political Sociology (pp. 291-341). Helsinki, Finland: The Academic Bookstore.

Linz, J. J. (1978). The Breakdown of Democratic Regimes: Crisis, Breakdown, and Reequilibration. Baltimore, MD: Johns Hopkins University Press.

Lust, E. \& Waldner, D. (2015). Unwelcome Change: Understanding, Evaluating, and Extending Theories of Democratic Backsliding. Retrieved January 20, 2021, from https://pdf. usaid.gov/pdf_docs/PBAAD635.pdf

Neto, O. A. \& Pimenta, G. A. (2020). The First Year of Bolsonaro in Office: Same Old Story, Same Old Song? Revista de Ciencia Política, no. 40(2), pp. 187-213. https://doi.org/10.4067/ S0718-090X2020005000103

Norris, P. (2017). Is Western Democracy Backsliding? Diagnosing the Risks. Harvard Kennedy School Working Paper No. RWP17-012. http://doi.org/10.2139/ssrn.2933655

OAS. (2018). Final Report of the Electoral Observation Mission, General Elections and Second Round, Brazil, 2018. Retrieved February 25, 2021, from http://www.oas.org/eomdatabase/ MoeReport.aspx? Lang=en\&Id=410\&MissionId $=490$

Planalto. (1983). Lei no 7.170, de 14 de dezembro de 1983. Retrieved February 12, 2021, from http://www.planalto.gov.br/ccivil_03/leis/17170.htm

Plattner, M. F. (2015). Is Democracy in Decline? Journal of Democracy, no. 26(1), pp. 5-10. https://doi.org/10.1353/jod.2015.0014

Público. (2020, June 5). Bolsonaro diz que manifestações pela democracia são organizadas por "marginais". Retrieved February 3, 2021, from https://www.publico.pt/2020/06/05/mundo/ noticia/bolsonaro-manifestacoes-democracia-sao-organizadas-marginais-1919562

Senado Federal. (2013). Constitution of the Federative Republic of Brazil. Retrieved March 11, 2021, from https://www2.senado.leg.br/bdsf/item/id/243334
Indicators of Authoritarian Behavior of Political Leaders. The Bolsonaro Case (2019-2020)

Adriano de Oliveira Othon 
Dossier América Latina: Brasil

Smith, M. (1997). El pluralismo. In D. Marsh \& G. Stoker (Eds.), Teoría y métodos de la ciencia política (pp. 217-234). Madrid, España: Alianza Editorial.

The Economist Intelligence Unit (2021). Democracy Index 2020: In Sickness and in Health? Retrieved March 11, 2021, from https://www.eiu.com/n/campaigns/democracyindex-2020/

UOL. (2019, March 31). Planalto distribui vídeo em defesa do golpe militar de 1964. Retrieved February 17, 2021, from https://noticias.uol.com.br/ultimas-noticias/agenciaestado/2019/03/31/planalto-distribui-video-em-defesa-do-golpe-militar-de-1964.htm

Veja. (2019, September 4). Bolsonaro exalta ditadura de Pinochet no Chile e ataca pai de Bachelet. Retrieved February 16, 2021, from https://veja.abril.com.br/mundo/bolsonaroexalta-ditadura-de-pinochet-no-chile-e-ataca-pai-de-bachelet/

V-Dem Institute (2021). Democracy Report 2021: Autocratization Turns Viral. Retrieved March 12, 2021, from https://www.v-dem.net/files/25/DR\%202021.pdf 